\title{
Promises and Obstacles of L1 Use in Language Classrooms: A State-of-the-Art Review
}

\author{
Mehdi Ghobadi ${ }^{1} \&$ Hadi Ghasemi ${ }^{2}$ \\ ${ }^{1}$ Faculty of Institute for Humanities and Cultural Studies (IHCS), Tehran, Iran \\ ${ }^{2}$ Faculty of Persian Literature and Foreign Languages, Islamic Azad University South Tehran Branch, Tehran, \\ Iran \\ Correspondence: Mehdi Ghobadi, Institute for Humanities and Cultural Studies (IHCS), Tehran, Iran. E-mail: \\ mehdi.ghobadi64@gmail.com
}

Received: September 4, 2015 Accepted: October 20, 2015 Online Published: October 23, 2015

doi:10.5539/elt.v8n11p245 URL: http://dx.doi.org/10.5539/elt.v8n11p245

\begin{abstract}
Translation and language teaching techniques which take language learners' first language (L1) as point of reference for teaching the second language (L2) have been long discouraged on the ground that these teaching techniques would end in the fossilization of L2 structure forms in the learner's Interlanguage system. However, in recent years, the status of $\mathrm{L} 1$ use in $\mathrm{L} 2$ teaching and learning has revived as a result of the recognition that L1 can serve purposes in L2 teaching and learning (Hunt, 2012). In the last two decades, strong theoretical arguments have been posed for L1 use in language classrooms. Most of these arguments are based on the ground that L1 use can facilitate the processes of both L2 teaching and acquisition. Abundant research has been done in recent years to validate these theoretical arguments. The current paper would give a review of this research, with reference to three L1-based techniques for language teaching and learning that have appealed most to L2 researchers (i.e., translation, code switching, and L1 glossing). The conclusion drawn from this research is that language learners can benefit L1 use and L1-based techniques in their L2 acquisition. Further, along with the theoretical arguments and empirical evidence in defense of L1 use in language classrooms, L2 learners and teachers have begun to express more positive attitudes towards L1 use, and related techniques, in their own classrooms. Yet, there remain some challenges and obstacles for L1 use in language use. Suggestions are made as to how to address these challenges so that L2 pedagogy and use would benefit most from L1 use in language classrooms.
\end{abstract}

Keywords: first language use, translation, code switching, first language glossing, language classrooms

\section{Introduction}

The use of translation as a tool in teaching and learning a second language (L2) has a history parallel to the history of language teaching itself. Looking at the documented history of L2 teaching and pedagogy (Howatt \& Widdowson, 2004; Richards \& Rodgers, 2014), we can observe that translation has been the main technique for teaching an L2. Particularly, this can be traced back to teaching the classic languages, (e.g., Latin and Greek). These classic languages usually lack native speakers who could use it for everyday oral interaction (Clackson \& Horrocks, 2011); yet, since these classic languages were usually associated with academic circles and knowledge of them was a sign of elitism, as they were languages of philosophy, literature, and fine arts, they enjoyed a rich written repertoire. As the materials for teaching these languages were written (e.g., literary classics, philosophical writings, poems, etc.), with learners having little-to-no opportunity to have contact with speakers of these languages, translation, and teaching techniques with reference to the learners' mother tongues, were considered as the most appropriate pedagogical tool in language classrooms. In this period, language classrooms were characterized by learners undertaking a lot of translation assignments, memorizing bilingual word lists, doing grammatical exercises, etc. (Howatt \& Widdowson, 2004).

Later, the above tradition was adopted in teaching English as a second/foreign language in the nineteenth and the early twentieth centuries. The time of the date was also ripe for this adoption; at the time, the popular learning 
theories of the date emphasized backbreaking learning exercises which could be observed in this tradition such as translation, memorization of bilingual word lists and grammatical exercises (Howatt \& Widdowson, 2004). The idea was that human mind required mental exercises for its growth. So, it was not surprising that the same methods used to teach the classic languages (i.e., the Grammar-Translation method) was adopted for teaching the modern languages (e.g., English and Spanish).

The emergence of behaviorism in the field of psychology, however, changed the state of the affairs. Language teaching researchers and practitioners sticking to the principles of behaviorism began to echo the idea that translation and other L1-based language teaching techniques should be totally removed from language classrooms as it was strongly believed that any use of learners' L1 would intervene with the process of L2 acquisition, resulting in the fossilization of erroneous L2 structures in learners' Interlanguage systems. Their justification was that, to achieve proficient levels of L2 knowledge, language learners should stay away from their mother tongue as far as possible so that $\mathrm{L} 1$ structures would not intervene with $\mathrm{L} 2$ structures. The influence of these behavioristic traditions on L2 research and pedagogy was so strong that, even decades after their fall in the fields of psychology and second language acquisition (SLA), they remain to influence some very important aspects of L2 pedagogy (Castagnaro, 2006). Language teachers are still fearful of L1 use in their language classrooms (Turnbull \& Dailey-O'Cain, 2009; Nagy \& Robertson, 2009) as they have been repeatedly reminded by the proponents of monolingual approaches to L2 acquisition that language classrooms should be held in the L2. According to Turnbull and Dailey-O'Cain (2009), educators still believe that

Avoiding interference from the learner's first language is necessary in effective language teaching and learning, and these educators may believe that avoiding code switching is the only way to ensure that the learner's first language does not interfere with target-language development. (Turnbull \& Dailey-O'Cain, 2009, p. 2)

However, the use of translation and other L1-based techniques in L2 research and pedagogy has revived in the last two decades (e.g., Cummins, 2001; Hunt, 2012; McMillan \& Turnbull, 2009). Language researchers have come to the recognition that, though these techniques may limit the language learners' exposure to comprehensible L2 input (Turnbull \& Dailey-O'Cain p. 2), they are nevertheless fruitful for the processes of L2 teaching and learning (Hunt, 2012). In fact, there are aspects of these processes that are handled most satisfactorily when references are made to the learners' mother tongue. Judicious use of the first language in second and foreign language learning and teaching was then recommended (e.g., Cummins, 2001) so that benefits that could take from such use would speed up the process of L2 acquisition in language classrooms. The objective of the current paper is to present a state-of-the-art review of the recent theorizing and research on the promises and uses that L1 use would have in language classrooms. It discusses the theoretical arguments set in defense of L1 in language classrooms, alongside with a snapshot of research findings showing the benefits of L1 use for L2 teaching and acquisition. This includes both research findings that showed L1 use would actually speed up the process of L2 acquisition and research findings on the learner's attitudes towards L1 use in language use. Further, challenges and obstacles of L1 use in language classrooms are discussed in summary, along with some suggestions on how to address these challenges and obstacles.

\section{Theoretical Arguments in Defense of First Language Use in Language Classrooms}

Most of the argument against the use of the first language in teaching the L2 has been mere theorizing, with little empirical evidence to support the argument. Therefore, it seems rather necessary to confront these arguments with the same weapon; that is, to establish theoretical grounds for using translation and L1-based techniques in language classrooms. In fact, there are several theoretical arguments for using L1 in language classrooms. The first argument usually set is that the process of second language teaching should work on what learners already know about the nature of language knowledge (Turnbull, \& Arnett, 2002). From the meaningful-learning point of view, any new learning material, including verbal materials, should be attached to a learner's mental structures of the similar nature so that the material could be assimilated in his/her mind as new knowledge (Ausubel, 1963). The argument goes that the learner's L2 provide such a platform for learning the L2. Metalinguistic comparisons and contrasts that language teachers make between the L1 and the L2 for their learners follow the same aim. As far as L2 acquisition is concerned, these comparisons and contrasts provide learners with a common ground for using and understanding the L2 or to move from L1 structures away and towards L2 structures.

A second argument for using L1 in language classrooms comes from the cognitive processing theory (Ellis, 2005; Macaro, 2009; Libben, 2000). According to the theory, bilinguals enjoy a shared conceptual store for L1 and L2 lexicons that is characterized by an increasing number of semantic connections that are not language-specific 
until they are required to be so based on the context of language use. The argument goes that, at elementary levels of L2 acquisition, it is better that language teachers and learners invest in those semantic connections that are more L1-based.

Since connections with the first language (especially in nonbalanced bilinguals) are going to be much stronger than connections with the second language, then to ignore the first language during the process of second language learning is to ignore an essential tool at the learner's disposal. (Macaro, 2009, p. 37)

A third argument for L1 use in L2 classrooms is that proposed from an identity perspective (e.g., Fuller, 2007; Fuller, Elsman, \& Self, 2007; Mori, 2014). According to Fuller (2007), for language learners and bilinguals, the choice between the L1 and the L2 is a matter of constructing identity. Language learners are said to feel more affiliated with the L2 if decent place is left for the use of their own mother tongue in the classroom. Learning a new language is complexly interwoven with constructing a new identity (Norton \& Toohey, 2011). This point is also defended in discussions of acculturation models of L2 acquisition. According to these models, the learner's potentiality to acquire an L2 depends on how much he/she would be assimilated into L2 cultural patterns (Brown, 2000). Closely linked to this argument is the proposition that L1 use may alleviate learners' L2 anxiety and boost their L2 motivation (Rolin-Ianziti \& Varshney, 2008). In our opinion, these functions are of paramount importance because they will increase their L2 self-confidence and this, in return, will increase learners' willingness to communicate through the L2 in classrooms. Elevated willingness to communicate through the L2 strongly determines how much L2 input the learner would receive and, thus, how L2 success would be achieved (MacIntyre, Baker, Clément, \& Conrod, 2001; Yashima, Zenuk - Nishide, \& Shimizu, 2004).

A final argument is based on the proposition that, sometimes, L1 use in language classrooms is not a matter of choice, but is rather inevitable. For example, it would be really hard to manage language classrooms, particularly at elementary levels, without the help of learners' mother tongue. From this viewpoint, L1 use can serve many managerial functions. Several of the managerial functions that L1 use can serve in language classrooms are as the following; giving assignments, creating a friendly classroom atmosphere, providing feedback, managing classroom discipline, and building rapport between the teacher and the leaner (Canagarajah, 1995; Dailey-O'Cain \& Liebscher, 2009; Rolin-Ianziti, \& Brownlie, 2002). It is believed that these functions are practically hard to serve using only the L2 in the classroom. This managerial function of L1 use in language classroom has the positive role of helping the learners not become confused between what is important to the process of L2 acquisition (i.e., the instructional content) and what is deployed to facilitate this process (i.e., logistics aspects of the process of L2 teaching). So it is highly recommended that, particularly at elementary levels, these managerial functions be handled through L1 use so that learners are able to focus their attentional resources on what is to be learned (Dailey-O'Cain \& Liebscher, 2009).

\section{Research Findings on L1 Use in Language Classrooms}

It is needless to say that only theoretical claims cannot justify L1 use in language classrooms and, thus it is necessary to see if the literature has any supporting empirical evidence to offer regarding the issue. As a matter of fact, along the theoretical claims proposed for L1 use in language classrooms in the last two decades, researchers have begun to conduct empirical research to see whether different L1-based techniques employed by language teachers would have beneficial effects on the process of L2 acquisition. These studies have been carried out on a number of techniques that make references to learners' mother tongue to teach aspects of the L2. However, the present review paper had to be selective in its presentation of the findings of these studies because of space limits. So, three of the most important L1-teachniques which had attracted the most attention in the SLA field were chosen for the review. The three L1-teachniques chosen for review were translation, code switching, and $\mathrm{L} 1$ glossing.

\subsection{Translation}

Translation is by far the oldest L1 techniques used in language classrooms. In fact, as mentioned before, translation and bilingual word lists were the major L2 teaching and technique techniques till the early twentieth century. Therefore, after the revitalization of $\mathrm{L} 1$ use in language classrooms, researchers began to investigate the question of whether translation would have beneficial effects on L2 acquisition processes. This line of research was undertaken in different areas of the L2.

For instance, some researchers conducted study to see whether translated L2 writing would be more effective than direct L2 writing (e.g., Cohen \& Brooks - Carson, 2001; Qi, 1998; Uzawa, 1996; Wang, 2003). For 
example, Cohen \& Brooks - Carson, (2001) asked 39 intermediate learners of L2 French to perform two writing tasks, one writing directly in the French and one writing fist composed in the learners' L1 (Spanish and English) and, then, translated into the French. The researchers used a multitrait scale for scoring the participants' writing assignments that scored the assignments according to the aspects deemed important to the process of writing (e.g., expression, transition, clauses, grammar, etc.). The findings of the study demonstrated that one-third of the participants did better on the translated writing task than on the direct writing task across all the measures of the rating scale. No difference was found between the quality of the translated writing task and the direct writing task for the remaining two-thirds of the participants. Cohen \& Brooks - Carson, (2001) also gathered data on the participants' attitudes towards the two modes of writing examined in their study (i.e., translated writing and direct writing). They found that most of the participants who benefited more from translated writing belong to the group who expressed more positive attitudes towards translated writing and most of the participants for whom no difference was found between translated and direct writing belonged to the group who expressed less positive attitudes towards translated writing. This shows that the benefits that language learners enjoy from L1 use in the process of L2 writing depends on their attitudes towards such use. Wang's (2003) study supported these findings.

Ramachandran and Abdul Rahim (2004) investigated the effects of translation on the acquisition and retention of L2 lexical items by elementary level ESL learners. In their study, they compared the acquisition and retention of twenty L2 lexical by two groups of ESL learners. The first group (control group) was taught the targeted lexical items by a non-translation method in which the participants were provided with the meanings of the lexical items in the L2 (English). The second group, on the other hand, was provided with the meanings of the lexical items in both the L1 (Malay) and L2. At the end of the treatment sessions (four sessions, one session each week), an immediate posttest of the targeted L2 lexical items was administered to both groups as a measure of the vocabulary acquisition and the same test was administered to the groups one month after each session as a measure of vocabulary retention. The results of the study demonstrated that the participants in the experimental group performed much better than participants in the control in the recall of the meaning of lexical items. In fact, except for Session 3, the participants in the translation group performed perfect in the immediate posttest while the participants in the non-translation group performed much lower than perfect. Even, in the immediate posttest on Session 3, the participants in the translation group performed very better than those in the non-translation group. In the delayed posttests, nearly the same results were obtained for the participants in the translation group while the performance of the participants in the non-translation group deteriorated a lot in the delayed posttests. The majority of the acquired target words were forgotten by the participants in the non-translation group till the delayed posttests. Ramachandran and Abdul Rahim (2004) vividly show that translation is a very effective tool for teaching and learning L2 vocabulary. Ramachandran and Abdul Rahim's findings have been supported by a recent study conducted by Joyce (2015) who also found that translation techniques would boost the acquisition and retention of L2 lexical items.

Kern (1994) is another study that investigated the role of translation in L2 acquisition and processing. His study tried to determine whether translation would facilitate the process of L2 reading comprehension. For this purpose, Kern asked Fifty-one intermediate-level French students to participate in think-aloud interviews while reading texts in the L2 French (see Bowles (2010) on think-aloud interviews and protocols in L2 research). The aim was to see whether mental translation that L2 readers engage in would improve their comprehension of L2 texts. As a matter of fact, Kern found that mental translation positively affects the quality and quantity of L2 reading comprehension processes. Kern concluded that mental translation seemed to facilitate students' L2 reading comprehension by removing

Affective barriers that often arise when students try to make sense of L2 texts. By making the input more familiar, putting it in "user-friendly" terms, the reader has greater confidence in his or her ability to comprehend the text. (p. 450)

All the above findings confirm the proposition that translation is an effective tool for processing and acquisition of different L2 skills and components.

\subsection{Code Switching}

The concept of code switching can be simply defined as bilinguals (both balanced and unbalanced) turning to either of languages based on the dynamics of the communication process and it often happens in spoken communication though it is not necessarily limited to spoken communication (for example, see Buell, 2004; Lin, 
2013; Qi, 1998). Some researchers (e.g., Dörnyei, 1995; Söderberg Arnfast \& Jørgensen, 2003) believe that, in case of language learners (i.e., unbalanced bilinguals), code switching is a communication strategy that learners would employ to cope with communication breakdowns. From this perspective, unlike balanced bilinguals, language learners are more conscious of their own turning towards either of the languages as the choice between the languages is a matter of which language would guarantee communication success. Further, this perspective puts forth some reasons to reject the traditional belief that code switching is harmful to the process of L2 acquisition. First, code switching is a common practice bilinguals do and this involves not only the unbalanced bilinguals with limited knowledge of the L2 but also those who are proficient in the L2 as well. In other words, like balanced bilingualism, code switching should be considered as a natural process in unbalanced bilingualism rather than thinking of it as a deviation from the objectives of L2 pedagogy.

A number of studies have been conducted in the SLA literature on code switching (e.g., Liebscher \& Dailey-O'Cain, 2005). For example, Liebscher and Dailey-O'Cain (2005) conducted a study to explore the functions that code switching would serve for the process of L2 acquisition, collecting their data during a seminar held for advanced learners of German. Confirming the previous propositions (e.g., Dörnyei, 1995; Söderberg Arnfast \& Jørgensen, 2003), the results of their study demonstrated that the most important function code switching served for the students was to compensate for situations when their L2 knowledge failed them. However, another important finding was that the students also resorted to their L1 even for non-compensatory purposes. Liebscher and Dailey-O'Cain (2005) found.

The students manifest their conception of the classroom as a bilingual space through their code-switching practices. When given permission to code-switch, these students did not merely fall back on the L1 when they encountered a deficiency in their L2 learning; they also made frequent use of language alternation to indicate changes in their orientation toward the interaction and toward each other.

Canagarajah (1995) too investigated the functions served by code switching. However, in contrast to Liebscher and Dailey-O'Cain (2005), Canagarajah (1995) was more interested in functions that code switching would serve for language teachers rather than learners. He analyzed code switched utterances produced by 24 secondary school English-as-a-Second-Language (ESL) teachers in Jaffna (Sri Lanka). Based on his analysis of the code switched utterances, Canagarajah claimed that code switching would serve two types of functions for ESL teachers; i.e., micro-functions and macro-functions. According to Canagarajah, under the first we will consider how code switching enables teachers and students to regulate classroom interactions or proceedings efficiently and systematically. Under the second, we will consider how code switching helps in the effective communication of the lesson content and language skills specified in the curriculum.

In other words, the micro-functions of code switching are concerned with classroom management issues (e.g., giving assignments, creating a friendly classroom atmosphere, providing feedback, managing classroom discipline, etc.) whereas the macro-functions of code switching deal with content transmission issues (e.g., explaining difficult L2 grammatical structures, giving the meanings of words, etc.). Such research findings show that code switching does not necessarily intervene with L2 teaching and learning processes; rather, it would serve functions that would ultimately contribute to these processes.

\subsection{Glossing}

The L1-based technique to be discussed in this section is usually used in teaching L2 reading comprehension and vocabulary development. Glossing is a language teaching technique in which the definitions of words are given in the margins of the reading comprehension texts to be read by the learner (see Hulstijn, Hollander, \& Greidanus, 1996; Schmitt, 2008). The definition can be given in either the learner's L1 or L2. To serve its own purposes, the current review papers would only focus on L1 glossing and the studies done on its effectiveness for L2 reading comprehension and lexical development.

The logic behind the use of glossing as a technique for teaching L2 reading comprehension is that it "provides accurate meanings for words that might not be guessed correctly" (Schmitt, 2008). When reading L2 texts, the learner may encounter words that are unknown to the learner but their meanings are essential to the comprehension of the texts. Glossing is supposed to be an appropriate teaching technique to facilitate the comprehension process. Moreover, when the learner processes the glossed words, it would contribute to the improvement of his/her knowledge of L2 vocabulary (e.g., Hulstijn et al., 1996; Schmitt, 2008).

A number of studies have been conducted in the SLA literature to see whether L1 glossing would facilitate the 
processes of L2 reading comprehension and lexical development (e.g., Davis, 1989; Hulstijn et al., 1996; Jacobs, Dufon, \& Fong, 1994; Yoshii, 2006)). For instance, Davis (1989) conducted a study to see whether L1 glossing would boost L2 reading comprehension. In his study, L2 reading comprehension was operationalized as the amount of the content the learners could remember/rewrite from the short story they read. Davis (1989) asked three groups of English learners of L2 French $(n=71)$ to read a French novel. The participants in the first group received L1 glosses for the difficult lexical items in the novel while the participants in the second group were provided with definitions of some vocabulary items before starting reading the short story. Finally, the participants in the last group, i.e., the control group, received no aids on the lexical items in the short story. The results of the study indicated that both of the experimental groups (i.e., L1 glossing and word definitions) performed significantly better on the recall task than those in the control group. Further, the participants in the L1-glossing group had a better performance on the recall task than the participants who received word definitions before reading. From these results, it was clear that providing L1 glosses for unknown words in an L2 text would improve L2 learners' depths of comprehension of the text.

Hulstijn et al. (1996) conducted a study with 78 Dutch university learners of L2 French who were asked to read a short French story. The target of their investigation was 16 French words embedded in the short story that were supposed to be unknown to the participants. The participants were classified into three treatments group. The participants in the first group read the short story while the meanings of the unknown words were glossed through the participants' L2 in the margins of the short story. The participants in the second group were allowed to look up the meanings of the unknown words from dictionaries when they encountered them. Finally, the participants in the third group, i.e., the control group, did not enjoy either L1 glossing or dictionary look-up; they only read the short story without any help.

The results of Hulstijn et al.'s (1996) study indicated that the participants in the L1-glossing group acquired and retained more of the targeted unknown words than those in both the look-up group and the control group. The participants in the L1-glossing group performed significantly better on an immediate posttest and a delayed posttest of the targeted words. Hulstijn et al. explained their findings by stating that L1 glossing would strengthen the form-meaning connections in the learner's mind that, in return, would result in increased L2 lexical development. Further Hulstijn et al. found that word frequency which had been shown to be a significant predictor of L2 lexical development would foster L2 knowledge particularly when it was associated with L1 glossing or dictionary look-up. The findings of Davis' (1989) and Hulstijn et al.'s (1996) studies on the positive role of L1 glossing in L2 reading comprehension and vocabulary development have been also supported by other studies too (e.g., Jacobs et al., 1994; Yoshii, 2006).

\section{Attitudes towards Translation and L1-based Techniques in Language Classrooms}

Along with the theoretical arguments that are presented for L1 use in L2 teaching and learning, it is now observed that, teachers and learners have begun to realize that L1 can serve important functions in language classrooms. A number of studies have been carried out to investigate language teachers and learners' towards L1 use in language classrooms (e.g., Brooks-Lewis, 2009; Edstrom, 2006; Kelly \& Bruen, 2015; Rolin-Ianziti \& Varshney, 2008). Rolin-Ianziti and Varshney (2008) is a study that investigated L1-English, L2-French learner's attitudes towards the use of L1 in language classrooms. The findings of their study indicated that the participants held positive attitudes towards L1 use in their classrooms. Specifically, the participants reported that L1 "allows access to vocabulary meaning and helps to explain the grammatical system of the TL [i.e., target language]" (p. 267). In other words, they attributed that the most significant function L1 use can serve was to transmit content related to L2 knowledge.

Kelly and Bruen (2015) too investigated the attitudes towards translation and L1 use but, this time, those attitudes held by language teachers rather than learners. In their study, Kelly and Bruen (2015) surveyed twelve language teachers (i.e., six German teachers and six Japanese teachers) about their attitudes towards L1 use, particularly translation, in their language classrooms. They found that the teachers investigated held strongly positive attitudes towards translation and L1 use in language classrooms. More interestingly, the teachers nearly reported the same reason for L1 use in language classrooms as the learners did in Rolin-Ianziti and Varshney's (2008) study. The teachers stated that the most immediate function translation can serve in language classrooms was to clarify the meanings of lexical items and to facilitate the instruction of grammatical structures. The following are two excerpts from the teachers in Kelly and Bruen's (2015) study:

In fourth year, it is useful as a vocabulary-building exercise. 
Translation helps to expand vocabulary and increase familiarity with structures in line with module learning outcomes. (p. 157)

Rolin-Ianziti and Varshney's (2008) and Kelly and Bruen's (2015) findings show two things. First, learners and teachers have already begun to question the longstanding belief that monolingual languages classrooms are more effective than bilinguals ones. Second, their study also showed that learners and teachers would, in fact, acted based upon their attitudes towards L1 use in L2 classrooms. As a matter of fact, the classrooms Rolin-Ianziti and Varshney (2008) and Kelly and Bruen (2015) observed in their studies were characterized by the feature that L1 use comprised a main tool for transmission of the L2 content and management of the classroom.

\section{Challenges and Obstacles of L1 Use in L2 Classrooms}

Though the above sections clearly demonstrate that L1 use can serve important functions in L2 acquisition, there are a number of challenges and obstacles for the use of L1 and L1-based techniques in L2 classrooms that need to be addressed. The most obvious obstacle for using the L1-based techniques in language classrooms is that it is only appropriate when all learners in the classroom possess the same mother tongue. Therefore, monolingual approaches that only make use of the target language in classrooms are more appropriate for such contexts. Further, even if L1 use is justified in L2 classrooms, teachers should take care of learner autonomy when letting their students make use of their mother tongue. Learners should not be driven to think that L1 can substitute the L2 whenever they encounter L2 communication problems. The problem is that learners would not feel pressured to develop their own L2 competence while responsibility and autonomy to learn the L2 is a prerequisite for acquiring it (Skehan, 1989). A side effect of such a situation is that learners' exposure to the L2 is decreased to the extent that the learners' mother tongue is used in the classroom. As Turnbull and Dailey-O'Cain (2009) state, "after all, unless it is compensated by further target-language talk, code switching reduces exposure to that all-important comprehensible input in the target language" (p. 2).

The above problems are the reasons why Macaro (2009) asserts that L1 be optimally used in language classrooms. By optimal L1 use, Macaro (2009) means L1 use that "can enhance second language acquisition and/or proficiency better than second language exclusivity" (p. 38). So, to avoid flooding language classrooms with L1 use that may harm the process of L2 acquisition, several suggestions for L1 use in language classrooms have been extracted from the literature as the following (e.g., Cook, 2001; Dailey-O'Cain \& Liebscher, 2009; Macaro, 2009; McMillan \& Turnbull, 2009; Rolin-Ianziti \& Brownlie, 2002):

- The teacher should not turn into L1 use because some L2 points might be too difficult for the learners to understand in the L2 (i.e., teacher avoidance strategy), the teacher should allow L1 use during L2 communication when all other more appropriate communication strategies have been trialed, when L1 is used to facilitate L2 comprehension, relative merits of L1 activation and use should be assessed against L2 input modification strategies, L1 use are more effective for teaching comprehension skills rather than productive skills though it could also serve significant functions in the latter, code switching must be deliberate and be decided in advance, and L1 use should not limit the amount of L2 input learners would receive in significant ways.

Suggestions like the above ones make us certain the challenges and obstacles for L1 use in language classrooms are optimized so that the best can be derived out of L1 use, and the use of L1-based techniques, in language classrooms. This, in return, results in the improvement of learners' L2 knowledge and L2 communication abilities that are the long-term objectives of language education efforts.

\section{Conclusion}

As stated at the beginning of the present state-of-the-art review, for decades, language teachers have been frightened of L1 use in their language classrooms. Most of the fear has been promulgated by monolingual language teaching methods which state that there is a necessity for the language learner to stay away from their mother tongue as far as possible when learning an L2 as any use of the L1 in the process of L2 learning may lead to fossilization of erroneous language structures in the learner's Interlanguage system. Further, according to Macaro (2001), the proponents of monolingual approaches to SLA believe that "learners do not need to understand everything that is said to them by the teacher and that switching to the first language (L1) undermines the learning process" (p. 531).

However, in the last two decades, these negative attitudes towards L1 use in language classrooms have been demystified by both theoretical arguments for L1 use in language classrooms and supporting empirical evidence on the issue. Some researchers have argued that judicious L1 use in classrooms provide learners with cognitive 
advantages for acquiring the L2. As a matter of fact, many empirical studies on the issue have supported the idea that judicious L1 use can facilitate the process of L2 acquisition. Along with these theoretical arguments and empirical evidence, teachers and learners have begun to express more positive attitudes towards L1 use in their language classrooms (e.g., Kelly \& Bruen, 2015; Rolin-Ianziti \& Varshney, 2008). They now believe that code switching is not a sign of deficient proficiency in unbalanced bilingualism but it is natural characteristic of such bilingualism $(\mathrm{Li}, 2000)$. Therefore, the question is not whether $\mathrm{L} 1$ use should be included in language classrooms, as it should be; rather, the question is how much and in what situations the teacher and learners can turn to L1 use in language classrooms. According to Macaro (2009), the optimal use is the yardstick for making such decisions, meaning that the final L2 achievements should be optimized as a result of L1 use in language classrooms. Yet, there are some challenges to L1 use in teaching and learning the L2. L1 would be of limited-to-no use in language teaching and learning contexts where the learners do not own the same mother tongue. In these contexts, monolingual approaches to L2 teaching would be more appropriate. Further, L1 use should not constrain the amount of L2 input learners are exposed to in the classroom. In our opinion, the future research should focus on the appropriate proportion of L1 use to L2 use in language classrooms. Further, studies should be carried out aspects of L1 use in L2 teaching and learning that have remained controversial.

\section{References}

Ausubel, D. (1963). Cognitive structure and the facilitation of meaningful verbal learning. Journal of Teacher Education, 14, 217-221. http://dx.doi.org/10.1177/002248716301400220

Bowles, M. A. (2010). The think-aloud controversy in second language research. London: Routledge.

Brooks-Lewis, K. A. (2009). Adult learners' perceptions of the incorporation of their L1 in foreign language teaching and learning. Applied Linguistics, 30, 216-235. http://dx.doi.org/10.1093/applin/amn051

Brown, H. D. (2000). Principles of language learning and teaching $\left(4^{\text {th }}\right.$ Ed.). New York: Longman.

Buell, M. Z. (2004). Code-switching and second language writing: How multiple codes are combined in a text. In C. Bazerman, \& P. Prior (Eds.), What writing does and how it does it: An introduction to analyzing texts and textual practices (pp. 97-122). Mahwah, NJ: Lawrence Erlbaum.

Canagarajah, A. S. (1995). Functions of code switching in ESL classrooms: Socializing bilingualism in Jaffna. Journal of Multilingual \& Multicultural Development, 16(3), 173-195. http://dx.doi.org/10.1080/01434632.1995.9994599

Castagnaro, P. J. (2006). Audio-lingual method and behaviorism: From misunderstanding to myth. Applied linguistics, 27(3), 519-526. http://dx.doi.org/10.1093/applin/aml023

Clackson, J., \& Horrocks, G. (2011). The Blackwell history of the Latin language. Oxford: Blackwell.

Cohen, A. D., \& Brooks - Carson, A. (2001). Research on direct versus translated writing: Students' strategies and their results. The Modern Language Journal, 85(2), 169-188. http://dx.doi.org/10.1111/0026-7902.00103

Cook, G. (2010). Translation in language teaching: An argument for reassessment. Oxford: Oxford University Press. http://dx.doi.org/10.1017/S0261444809990140

Cook, V. (2001). Using the first language in the classroom. Canadian Modern Language Review, 57(3), 402-423. http://dx.doi.org/10.3138/cmlr.57.3.402

Cummins, J. (2001) Negotiating identities: Education for empowerment in a diverse society (2 ${ }^{\text {nd }}$ ed.). Los Angeles: California Association for Bilingual Education.

Dailey-O'Cain, J., \& Liebscher, G. (2009). Teacher and student use of the first language in foreign language classroom interaction: Functions and applications. In M. Turnbull, \& J. Dailey-O'cain (Eds.), First language use in second and foreign language learning (pp. 131-144). Toronto: Multilingual Matters.

Davis, J. N. (1989). Facilitating effects of marginal glosses on foreign language reading. The Modern Language Journal, 73(1), 41-48. http://dx.doi.org/10.1111/j.1540-4781.1989.tb05308.x

Dörnyei, Z. (1995). On the teachability of communication strategies. TESOL Quarterly, 29, 55-84. http://dx.doi.org/10.2307/3587805

Edstrom, A. (2006). L1 Use in the L2 Classroom: One teacher's self-evaluation. The Canadian Modern 
Language Review, 3, 275-292. http://dx.doi.org/10.3138/cmlr.63.2.275

Ellis, N. (2005). At the interface: Dynamic interactions of explicit and implicit language knowledge. Studies in Second Language Acquisition, 27, 305-352. http://dx.doi.org/10.1017/s027226310505014x

Fuller, J. M. (2007). Language choice as a means for shaping identity. Journal of Linguistic Anthropology, 17(1), 105-129. http://dx.doi.org/10.1525/jlin.2007.17.1.105

Fuller, J., Elsman, M., \& Self, K. (2007). Addressing peers in a Spanish-English bilingual classroom. In K. Potowski, \& R. Cameron (Eds.), Spanish in contact: Policy, social, and linguistic inquiries (pp. 135-151). Amsterdam: John Benjamins. http://dx.doi.org/10.1075/impact.22.12ful

Howatt, A. P. R., \& Widdowson, H. G. (2004). A history of English language teaching (2nd Ed.). Oxford: Oxford University Press.

Hunt, N. D. (2012). Managing Method: A critical inquiry into language policy in a tertiary institution in the United Arab Emirates. RELC Journal, 43(3), 295-311. http://dx.doi.org/10.1177/0033688212463295

Hulstijn, J. H., Hollander, M., \& Greidanus, T. (1996). Incidental vocabulary learning by advanced foreign language students: The influence of marginal glosses, dictionary use, and reoccurrence of unknown words. The Modern Language Journal, 80(3), 327-339. http://dx.doi.org/10.1111/j.1540-4781.1996.tb01614.x

Jacobs, G. M., Dufon, P., \& Fong, C. H. (1994). L1 and L2 vocabulary glosses in L2 reading passages: Their effectiveness for increasing comprehension and vocabulary knowledge. Journal of Research in Reading, 17, 19-28. http://dx.doi.org/10.1111/j.1467-9817.1994.tb00049.x

Joyce, P. (2015). L2 vocabulary learning and testing: the use of L1 translation versus L2 definition. The Language Learning Journal, (ahead-of-print), 1-12. http://dx.doi.org/10.1080/09571736.2015.1028088

Kelly, N., \& Bruen, J. (2015). Translation as a pedagogical tool in the foreign language classroom: A qualitative study of attitudes and behaviors. Language Teaching Research, 19(2), 150-168. http://dx.doi.org/10.1177/1362168814541720

Kern, R. G. (1994). The role of mental translation in second language reading. Studies in second language acquisition, 16(04), 441-461. http://dx.doi.org/10.1017/S0272263100013450

Li, W. (2000) Dimensions of bilingualism. In W. Li (Ed.) The Bilingualism Reader (pp. 3-25). London: Routledge.

Libben, G. (2000) Representation and processing in the second language lexicon: The homogeneity hypothesis. In J. Archibald (Ed.) Second Language Acquisition and Linguistic Theory (pp. 228-248). Oxford: Blackwell.

Liebscher, G., \& Dailey-O'Cain, J. (2005). Learner code - switching in the content - based foreign language $\begin{array}{lllll}\text { classroom. The Modern } & \text { Language Journal, }\end{array}$ http://dx.doi.org/10.1111/j.1540-4781.2005.00277.x

Lin, A. M. Y. (2013). Classroom code-switching: Three decades of research. Applied Linguistics Review, 4(1), 195-218. http://dx.doi.org/10.1515/applirev-2013-0009

Macaro, E. (2001). Analyzing student teachers' code switching in foreign language classrooms: Theories and decision-making. The Modern Language Journal, 85(4), 531-548. http://dx.doi.org/10.1111/0026-7902.00124

Macaro, E. (2009). Teacher use of code switching in the second language classroom: Exploring 'optimal' use. In M. Turnbull, \& J. Dailey-O'cain (Eds.), First language use in second and foreign language learning (pp. 35-49). Toronto: Multilingual Matters.

MacIntyre, P. D., Baker, S. C., Clément, R., \& Conrod, S. (2001). Willingness to communicate, social support, and language-learning orientations of immersion students. Studies in second language acquisition, 23(03), 369-388. http://dx.doi.org/10.1017/S0272263101003035

McMillan, B., \& Turnbull, M. (2009). Teachers' use of the first language in French immersion: Revisiting a core principle. In M. Turnbull \& J. Dailey-O'cain (Eds.), First language use in second and foreign language learning (pp. 15-34). Toronto: Multilingual Matters.

Mori, M. (2014). Conflicting ideologies and language policy in adult ESL: Complexities of language 
socialization in a majority-L1 classroom. Journal of Language, Identity \& Education, 13(3), 153-170. http://dx.doi.org/10.1080/15348458.2014.919810

Norton, B., \& Toohey, K. (2011). Identity, language learning, and social change. Language Teaching, 44(4), 412-446. http://dx.doi.org/10.1017/S0261444811000309

Qi, D. (1998). An inquiry into language switching in second language composing processes. Canadian Modern Language Review, 54(3), 413-435. http://dx.doi.org/10.3138/cmlr.54.3.413

Ramachandran, S. D., \& Rahim, H. A. (2004). Meaning recall and retention: The impact of the translation method on elementary level learners' vocabulary learning. RELC journal, 35(2), 161-178. http://dx.doi.org/10.1177/003368820403500205

Richards, J. C., \& Rodgers, T. S. (2014). Approaches and methods in language teaching (3rd Ed.). Cambridge: Cambridge University Press.

Rolin-Ianziti, J., \& Brownlie, S. (2002). Teacher use of learners' native language in the foreign language classroom. Canadian Modern Language Review, 58(3), 402-426. http://dx.doi.org/10.3138/cmlr.58.3.402

Rolin-Ianziti, J., \& Varshney, R. (2008). Students' views regarding the use of the first language: An exploratory study in a tertiary context maximizing target language use. Canadian modern language review, 65(2), 249-273. http://dx.doi.org/10.3138/cmlr.65.2.249

Schmitt, N. (2008). Review article: Instructed second language vocabulary learning. Language Teaching Research, 12(3), 329-363. http://dx.doi.org/10.1177/1362168808089921

Skehan, P. (1989). Individual differences in second language learning. London: Edward Arnold.

Söderberg Arnfast, J., \& Jørgensen, J. N. (2003). Code - switching as a communication, learning, and social negotiation strategy in first - year learners of Danish. International Journal of Applied Linguistics, 13(1), 23-53. http://dx.doi.org/10.1111/1473-4192.00036

Turnbull, M., \& Arnett, K. (2002). Teachers' use of the target and first languages in second and foreign language classrooms. Annual Review of Applied Linguistics, 22, 204-208. http://dx.doi.org/10.1017/s0267190502000119

Turnbull, M., \& Dailey-O'Cain, J. (2009). Introduction. In M. Turnbull, \& J. Dailey-O'cain (Eds.), First language use in second and foreign language learning (pp. 1-14). Toronto: Multilingual Matters.

Uzawa, K. (1996). Second language learners' processes of L1 writing, L2 writing, and translation from L1 into L2. Journal of second language writing, 5(3), 271-294. http://dx.doi.org/10.1016/S1060-3743(96)90005-3

Wang, L. (2003). Switching to first language among writers with differing second-language proficiency. Journal of Second Language Writing, 12(4), 347-375. http://dx.doi.org/10.1016/j.jslw.2003.08.003

Wundt, W. (1904). Principles of physiological psychology (E. B. Titchener, Trans.). London: Swan Sonnenschein. (Original work published 1874).

Yashima, T., Zenuk - Nishide, L., \& Shimizu, K. (2004). The influence of attitudes and affect on willingness to communicate and second language communication. Language learning, 54(1), 119-152. http://dx.doi.org/10.1111/j.1467-9922.2004.00250.x

Yoshii, M. (2006). L1 and L2 glosses: Their effects on incidental vocabulary learning. Language Learning and Technology, 10(3), 85-101.

\section{Copyrights}

Copyright for this article is retained by the author(s), with first publication rights granted to the journal.

This is an open-access article distributed under the terms and conditions of the Creative Commons Attribution license (http://creativecommons.org/licenses/by/3.0/). 